Jurnal Ekonomi Syariah Teori dan Terapan p-ISSN: 2407-1935, e-ISSN: 2502-1508. Vol. 8 No. 5

September 2021: 570-581; DOI: 10.20473/vol8iss20215pp570-581

\title{
ANALISIS TINGKAT KESEHATAN BANK DAN POTENSI FINANCIAL DISTRESS MENGGUNAKAN METODE RGEC DAN ZMIJEWSKI PADA BANK BNI SYARIAH TAHUN 2015-2019
}

\section{ANALYSIS OF BANK HEALTH LEVELS AND THE POTENTIAL OF FINANCIAL DISTRESS USING RGEC AND ZMIJEWSKI METHODS AT BANK BNI SYARIAH 2015-2020}

\author{
Muhammad Iqbal Surya Pratikto, Mohammad Khoiruzi Afiq \\ Ekonomi Syariah, Fakultas Ekonomi dan Bisnis Islam UIN Sunan Ampel Surabaya \\ m.iqbal@uinsby.ac.id*, khoiruziafiq@gmail.com
}

\begin{abstract}
ABSTRAK
Perkembangan perbankan syariah yang sangat pesat telah membuat bank syariah memiliki peran strategis dalam roda perekonomian. Hal ini ditandai dengan semakin besarnya jumlah Bank Umum Syariah (BUS) dan Unit Usaha Syariah (UUS) yang saat ini mencapai 34 dengan 828 KPO/KC (Kantor Pusat Operasional/Kantor Cabang), 1.440 KCP/UPS (Kantor Cabang Pembantu/Unit Pelayanan Syariah) dan 544 KK (Kantor Kas). Penilaian tingkat kesehatan perbankan sangatlah penting, tidak hanya untuk internal perusahaan, melainkan investor, pemerintah bahkan masyarakat. Penilaian tersebut juga dapat digunakan sebagai upaya untuk menilai kinerja dan mendeteksi terjadinya potensi kebangkrutan. BNI Syariah merupakan perbankan syariah yang menduduki peringkat keempat dengan kategori kapitalisasi pasar sebagai bank syariah terbesar di Indonesia. Penelitian ini bertujuan untuk mengetahui tingkat kesehatan dan potensi financial distress pada BNI Syariah periode 2015-2020 menggunakan metode RGEC dan Zmijewski. Metode penelitian ini menggunakan metode kuantitatif deskriptif. Objek penelitian ini adalah laporan keuangan BNI Syariah tahun 2015-2020. Hasil penelitian ini menunjukkan bahwa tingkat kesehatan BNI Syariah tahun 2015-2020 menggunakan metode RGEC dan Zmijewski mendapatkan predikat sangat sehat dan stabil atau tidak berpotensi mengalami financial distress. Sehingga kinerja BNI Syariah dapat dikatakan sangat baik dalam menghadapi pengaruh negatif dari fluktuasi bisnis.
\end{abstract}

Kata Kunci: Kesehatan Bank, Financial Distress, RGEC, Zmijewsk.

\section{ABSTRACT}

The development of Islamic banking is very fast and has made Islamic banks have a strategic role in the wheels of the economy. This is indicated by the increasing number of Sharia Commercial Banks (BUS) and Sharia Business Units (UUS) which currently reach 34 with 828 KPO / KC (Operational Headquarters / Branch Offices), 1,440 KCP / UPS (Sub-Branch Offices / Service Units). Sharia) and 544 KK (Cash Office). Assessment of the soundness of banking is very important, not only for internal companies, but for investors, government and even the community. This assessment can also be used as an effort to assess performance and detect potential bankruptcies. BNI Syariah is a sharia banking which is ranked fourth in the market capitalization category as the largest sharia bank in Indonesia. This study aims to determine the level of health and potential financial distress in BNI Syariah for the 2015-2020 period using the RGEC and Zmijewski methods. This research method uses descriptive quantitative methods. The object of this research is the 2015-2020 BNI Syariah financial statements. The results of this study indicate that the health level of BNI Syariah in 2015-2020 using the RGEC and Zmijewski methods gets the predicate very healthy and stable or does not have the potential to experience financial distress. So that the performance of BNI Syariah can be said to be very good in facing the negative effects of business fluctuations.

Keywords: Bank Health, Financial Distress, RGEC, Zmijewsk.
Informasi artikel

Diterima: 25-04-2021

Direview: $15-08-2021$

Diterbitkan: 30-09-2021

${ }^{*}$ Korespondensi (Correspondence): Muhammad Iqbal Surya Pratikto

Open access under Creative Commons Attribution-Non Commercial-Share A like 4.0 International Licence (CC-BY-NC-SA) (c) (1) (\$) 


\section{PENDAHULUAN}

Perbankan syariah menjadi salah satu lembaga keuangan yang memiliki peran strategis dalam perekonomian. Berdasarkan data dari Otoritas Jasa Keuangan (OJK) tahun 2020, perkembangan bank syariah sangatlah pesat ditandai dengan semakin besar jumlah Bank Umum Syariah (BUS) dan Unit Usaha Syariah (UUS) yang saat ini mencapai 34 dengan 828 Kantor Pusat Operasional ataupun Kantor Cabang, 1.440 Kantor Cabang Pembantu ataupun Unit Pelayanan Syariah dan 544 Kantor Kas. Menurut Undang-undang No. 10 tahun 1998 menyatakan bahwa bank merupakan lembaga yang dibentuk untuk meningkatkan taraf hidup rakyat banyak melalui proses penghimpunan dana dari masyarakat dalam bentuk simpanan dan menyalurkannya dalam bentuk kredit atau bentuk lainnya.

Dalam menjalankan peranannya sebagai lemabaga intermediasi, perbankan harus memperhatikan aspek risiko yang diakibatkan dari kegiatan operasional pengelolaan dananya. Terlebih karena perbankan mengelola dana masyarakat yang dititipkan pada bank. Oleh karena itu, perbankan wajib untuk memelihara dan menjaga amanah dari masyarakat dengan cara mengelola dana dengan prinsip kehati-hatian dengan mempertimbangkan manajemen risiko yang dapat berpengaruh terhadap tingkat kesehatan bank (Pratikto et al., 2019).

Kesehatan bank merupakan suatu kondisi dimana bank mampu menjalankan aktivitas operasional dengan stabil dan mampu memenuhi semua kewajibannya dengan baik sesuai dengan perturan yang berlaku (Rahmat, 2020). Sedangkan menurut Anik dan Ningsih (2020) suatu bank dapat dikatakan sehat apabila bank tersebut mampu menjalankan fungsinya dengan baik sebagai lembaga intermediasi, mampu memelihara dan menjaga kepercayaan masyarakat serta dapat membantu pemerintah dalam melaksanakan berbagai kebijakan terutama dalam bidang moneter (Anik \& Ningsih, 2020).

Penilaian tingkat kesehatan suatu perbankan dapat dilakukan menggunakan analisa dari hasil laporan keuangan yang dipublikasi oleh bank. Laporan keuangan merupakan laporan yang menunjukkan kondisi keuangan suatu perusahaan saat periode tertentu untuk melihat baik atau tidaknya kinerja perusahaan tersebut (Ardyanfitri et al., 2019). Dalam hal ini, publikasi laporan keuangan yang dilakukan oleh perbankan menjadi salah satu bentuk upaya untuk menjaga akuntabilitas dan transparansi dalam pengelolaan dana masyarakat. Hal ini sesuai dengan firman Allah SWT dalam AlQur`an surat An-Nisa` ayat 58:

"Sesungguhnya Allah menyuruh kamu menyampaikan amanat kepada yang berhak menerimanya dan (menyuruh kaтu) apabila menetapkan hukum diantara manusia supara kamu menetapkan dengan adil. Sesungguhnya Allah memberi pengajaran yang sebaik-baiknya kepadamu. Sesungguhnya Allah adalah Maha Mendengar lagi Maha Melihat." (QS. An-Nisa`ayat 58).

Kesehatan bank juga dapat digunakan untuk mendeteksi dan mengantisipasi terjadinya financial distress yang berpotensi pada kebangkrutan perusahaan. Terdapat beberapa model yang dapat digunakan dalam memprediksi terjadinya potensi kebangkrutan yaitu metode Z-score Atlman, Springrate, Zmijewski, dan Grover (Ardyanfitri et al., 2019).

Gejolak ekonomi yang muncul selama beberapa tahun terakhir mengindikasikan bahwa inovasi dalam produk, jasa dan aktivitas perbankan perlu memerhatikan manajemen risiko yang memadai. Oleh karena itu, Bank Indonesia menyempurnakan metode penilaian tingkat kesehatan bank yang semula menggunakan metode CAMELS yang terdiri dari (Capital, Assets, Management, Earnings, Liquidty, dan Sensitivity to Market Risk) menjadi RGEC (Risk Profile, Governance, Earnings, dan Capital) sesuai dengan Surat Edara Bank Indonesia (SEBI) No. 13/24/DPNP tanggal 25 Oktober 2011 tentang Penilaian Tingkat kesehatan Bank Umum (Hafiz.Pdf, n.d.).

BNI Syariah merupakan perbankan syariah yang didirikan sejak tahun 2010 dan dari segi kapitalisasi pasar menduduki peringkat ke Empat sebagai bank syariah terbesar di Indonesia. Selain itu, BNI syariah juga mendapatkan penghargaan predikat bank syariah terbaik 2019 kategori bank syariah aset di atas Rp 20 Triliun. Oleh karena itu, BNI Syariah menjadi salah satu perbankan syariah yang memiliki peran strategis dalam menggerakkan roda perekonomian dan menjadi pilihan bagi masyarakat. Berdasarkan uraian diatas, maka penulis melakukan penelitian dengan judul "Analisis Tingkat Kesehatan dan Potensi Financial Distress Menggunakan Metode RGEC dan Zmijewski Pada Bank BNI Syariah Tahun 2015-2020". 


\section{LANDASAN TEORI DAN PENGEMBANGAN HIPOTESIS}

\section{Tingkat Kesehatan Bank}

Kesehatan bank merupakan suatu kondisi dimana bank mampu menjalankan aktivitas operasional dengan stabil dan mampu memenuhi semua kewajibannya dengan baik sesuai dengan perturan yang berlaku (Rahmat, 2020). Kesehatan bank merupakan gambaran baik atau buruknya kondisi keuangan, pengelolaan dan kegiatan operasional dari perbankan (Tho'in \& Irawati, 2018).

\section{Metode RGEC}

Metode RGEC merupakan hasil pengembangan dari metode CAMELS. Metode ini dapat digunakan sebagai alat untuk mengukur tingkat kesehatan bank. Dalam penilaian kesehatan bank menggunakan metode RGEC terdapat empat komponen utama yang diukur yaitu:

\section{Risk Profile}

Profil risiko adalah seluruh risiko yang melekat pada perbankan diakibatkan oleh kegiatan operasional perbankan yang dapat mempengaruhi kinerja keuangan (Sirait et al., 2020). Berdasarkan peraturan Bank Indonesia Nomor 13/1/PBI/2011 tentang Penilaian Tingkat Kesehatan Bank Umum menyatakan bahwa risiko profil merupakan penilaian seluruh risiko inheren dan kualitas manajemen risiko dalam operasional perbankan yang mencakup delapan risiko yaitu risiko kredit, risiko pasar, risiko likuiditas, risiko operasional, risiko hukum, risiko stratejik, risiko kepatuhan dan risiko reputasi. Dalam RGEC profil risiko diukur menggunakan dua indikator yakni risiko kredit dan risiko likuiditas.

Risiko kredit merupakan suatu kondisi di mana pihak debitur tidak mampu menyelesaikan kewajibannya kepada kreditur secara tepat waktu baik pada saat jatuh tempo maupun sesudah jatuh tempo sesuai dengan kesepakatan dan aturan yang berlaku. Risiko ini dapat diukur melalui NPF (Non Performing Finance) (Dewi \& Srihandoko, 2018). Adapun rumus perhitungan NPF sebagai berikut:

$$
\begin{gathered}
\mathrm{NPF}=\frac{\text { Pembiayaan Bermasalah }}{\text { Total Kredit }} \times 100 \% \\
\text { Tabel } 1 .
\end{gathered}
$$

Klasifikasi Peringkat Komposit NPF

\begin{tabular}{|c|c|c|}
\hline Peringkat & Kriteria & Predikat \\
\hline 1 & $\mathrm{NPF} \leq 2 \%$ & Sangat Sehat \\
\hline 2 & $2 \%<\mathrm{NPF} \leq 5 \%$ & Sehat \\
\hline 3 & $5 \%<\mathrm{NPF} \leq 8 \%$ & Cukup Sehat \\
\hline 4 & $8 \%<\mathrm{NPF} \leq 12 \%$ & Kurang Sehat \\
\hline 5 & $\mathrm{NPF}>12 \%$ & Tidak Sehat \\
\hline
\end{tabular}

Sumber: Peraturan Bank Indonesia Nomor 6/10/PBI/2004

Risiko likuiditas merupakan suatu kondisi dimana perusahaan tidak mampu dalam memenuhi liabilitas lancarnya dari aset likuid yang dimilikinya sehingga berdampak pada ketidakstabilan aktivitas perusahaan (Adhim, 2019). Risiko ini dapat diukur menggunakan Financing to Deposit Ratio (FDR) (Dewi \& Srihandoko, 2018). Adapun rumus perhitungan FDR sebagai berikut:

$$
\mathrm{FDR}=\frac{\text { Total Pembiayaan }}{\text { Total Dana Pihak Ketiga (DPK) }} \times 100 \%
$$

Tabel 2.

Klasifikasi Peringkat Komposit FDR

\begin{tabular}{|c|c|c|}
\hline Peringkat & Kriteria & Predikat \\
\hline 1 & FDR $\leq 75 \%$ & Sangat Sehat \\
\hline 2 & $75 \%<$ FDR $\leq 85 \%$ & Sehat \\
\hline 3 & $85 \%<$ FDR $\leq 100 \%$ & Cukup Sehat \\
\hline 4 & $100 \%<$ FDR $\leq 120 \%$ & Kurang Sehat \\
\hline 5 & FDR $>120 \%$ & Tidak Sehat \\
\hline
\end{tabular}

Sumber: Peraturan Bank Indonesia Nomor 6/10/PBI/2004

\section{Good Corporate Governance}

Good corporate governance (GCG) merupakan sebuah sistem dalam pengelolaan perusahaan yang dapat menciptakan nilai tambah (value added) untuk semua pihak yang berkepentingan dengan 
perusahaan (stakeholder) baik itu investor, perusahaan, kreditur, pemerintah, maupun masyarakat luas(Halimatusadiah \& Gunwan, 2014). Penerapan Good Corporate Governance dapat meningatkan kinerja hingga akuntanbilitas perusahaan serta meningkatkan kepercayaan masyarakat terhadap perusahaan sehingga menjadi kunci sukses bagi perusahaan untuk memperoleh keuntungan jangka panjang dan dapat bersaing dalam taraf internasional. GCG dapat diukur melalui rasio Posisi Devisa Neto (PDN) (Suryanto \& Refianto, 2019). Adapun rumus perhitungan PDN sebagai berikut:

$$
\begin{gathered}
\mathrm{PDN}=\frac{\text { Selisih Aset dan Liabilitas Valas }}{\text { Total Modal }} \times 100 \% \\
\text { Tabel } 3 .
\end{gathered}
$$

Klasifikasi Peringkat Komposit PDN

\begin{tabular}{|c|c|c|}
\hline Peringkat & Kriteria & Predikat \\
\hline 1 & Tidak ada pelanggaran rasio PDN & Sangat Sehat \\
\hline 2 & Pelanggaran sudah diselesaikan & Sehat \\
\hline 3 & $0 \%<$ PDN $\leq 10 \%$ & Cukup Sehat \\
\hline 4 & $10 \%<$ PDN $\leq 25 \%$ & Kurang Sehat \\
\hline 5 & FDR $>25 \%$ & Tidak Sehat \\
\hline
\end{tabular}

Sumber: Peraturan Bank Indonesia Nomor 6/10/PBI/2004

\section{Earnings}

Rentabilitas merupakan alat yang digunakan untuk mengukur tingkat efisiensi perusahaan dalam menghasilkan keuntungan atau laba dengan menggunakan modalnya dalam periode tertentu (Samanto \& Hidayah, 2020). Penilaaian faktor rentabilitas meliputi evaluasi terhadap kinerja rentabilitas, sumber-sumber rentabilitas, kesinambungan rentabilitas dan manajemen rentabilitas bank syariah. Terdapat beberapa komponen yang digunakan dalam pengukuran rentabilitas yaitu ROA (Return On Assets), ROE (Return On Equity), NI (Net Imbalan) dan BOPO (Biaya Operasional Terhadap Pendapatan Operasional) (Wahasusmiah \& Watie, 2018).

1. Rumus perhitungan ROA

$$
\begin{aligned}
& \text { ROA }=\frac{\text { Laba Sebelum Pajak }}{\text { Total Aktiva }} \times 100 \% \\
& \text { Tabel } 4 . \\
& \text { Klasifikasi Peringkat Komposit ROA }
\end{aligned}
$$

\begin{tabular}{|c|c|c|}
\hline Peringkat & Kriteria & Predikat \\
\hline 1 & ROA $\geq 2 \%$ & Sangat Sehat \\
\hline 2 & $1,25 \% \leq \mathrm{ROA}<2 \%$ & Sehat \\
\hline 3 & $0,5 \% \leq \mathrm{ROA}<1,25 \%$ & Cukup Sehat \\
\hline 4 & $0 \% \leq \mathrm{ROA}<0,5 \%$ & Kurang Sehat \\
\hline 5 & $\mathrm{ROA}<0 \%$ & Tidak Sehat \\
\hline
\end{tabular}

Sumber: Peraturan Bank Indonesia Nomor 6/10/PBI/2004

2. Rumus perhitungan ROE

$$
\begin{gathered}
\text { ROE }=\frac{\text { Laba Setelah Pajak }}{\text { Total Modal }} \times 100 \% \\
\text { Tabel } 5 .
\end{gathered}
$$

Klasifikasi Peringkat Komposit ROE

\begin{tabular}{|c|c|c|}
\hline Peringkat & Kriteria & Predikat \\
\hline 1 & $\mathrm{ROE} \geq 20 \%$ & Sangat Sehat \\
\hline 2 & $12,5 \% \leq \mathrm{ROE}<20 \%$ & Sehat \\
\hline 3 & $5 \% \leq \mathrm{ROE}<12,5 \%$ & Cukup Sehat \\
\hline 4 & $0 \% \leq \mathrm{ROE}<5 \%$ & Kurang Sehat \\
\hline 5 & $\mathrm{ROE}<0 \%$ & Tidak Sehat \\
\hline
\end{tabular}

Sumber: Peraturan Bank Indonesia Nomor 6/10/PBI/2004

3. Rumus perhitungan NI

$$
\mathrm{NI}=\frac{\text { Pendapatan Imbalan }}{\text { Aset Produktif }} \times 100 \%
$$


Tabel 6.

Klasifikasi Peringkat Komposit NI

\begin{tabular}{|c|c|c|}
\hline Peringkat & Kriteria & Predikat \\
\hline 1 & $\mathrm{NI} \geq 6,5 \%$ & Sangat Sehat \\
\hline 2 & $2 \% \leq \mathrm{NI}<6,5 \%$ & Sehat \\
\hline 3 & $1,5 \% \leq \mathrm{NI}<2 \%$ & Cukup Sehat \\
\hline 4 & $0 \% \leq \mathrm{NI}<1,5 \%$ & Kurang Sehat \\
\hline 5 & $\mathrm{NI}<0 \%$ & Tidak Sehat \\
\hline
\end{tabular}

Sumber: Peraturan Bank Indonesia Nomor 6/10/PBI/2004

4. Rumus perhitungan BOPO

$$
\mathrm{BOPO}=\frac{\text { Biaya Operasional }}{\text { Pendapatan Operasional }} \times 100 \%
$$

Tabel 7.

Klasifikasi Peringkat Komposit BOPO

\begin{tabular}{|c|c|c|}
\hline Peringkat & Kriteria & Predikat \\
\hline 1 & BOPO $\leq 88 \%$ & Sangat Sehat \\
\hline 2 & $88 \%<\mathrm{BOPO} \leq 93 \%$ & Sehat \\
\hline 3 & $93 \%<\mathrm{BOPO} \leq 96 \%$ & Cukup Sehat \\
\hline 4 & $96 \%<\mathrm{BOPO} \leq 100 \%$ & Kurang Sehat \\
\hline 5 & $\mathrm{BOPO}>100 \%$ & Tidak Sehat \\
\hline
\end{tabular}

Sumber: Peraturan Bank Indonesia Nomor 6/10/PBI/2004

\section{Capital}

Capital dapat diartikan sebagai modal yang dimiliki perbankan. Penilaian atas permodalan suatu perbankan meliputi kecukupan dan kualitas dari pengelolaan permodalan. Dalam melakukan perhitungan permodalan, perbankan harus mengikuti standar yang ditetapkan oleh Bank Indonesia mengenai Kewajiban Penyediaan Modal Minimum (KPPM) untuk menanggulangi risiko. Capital dapat diukur melalui indikator Capital Adequacy Ratio (CAR). Adapun rumus perhitungan CAR sebagai berikut:

$$
\begin{gathered}
\mathrm{CAR}=\frac{\text { Modal }}{\text { Aset Tertimbang Menurut Risiko }} \times 100 \% \\
\text { Tabel } 8 .
\end{gathered}
$$

Klasifikasi Peringkat Komposit CAR

\begin{tabular}{|c|c|c|}
\hline Peringkat & Kriteria & Predikat \\
\hline 1 & CAR $\geq 12 \%$ & Sangat Sehat \\
\hline 2 & $9 \% \leq \mathrm{CAR}<12 \%$ & Sehat \\
\hline 3 & $8 \% \leq \mathrm{CAR}<9 \%$ & Cukup Sehat \\
\hline 4 & $6 \% \leq \mathrm{CAR}<8 \%$ & Turang Sehat \\
\hline 5 & CAR $<6 \%$ & Tidak Sehat \\
\hline
\end{tabular}

Sumber: Peraturan Bank Indonesia Nomor 6/10/PBI/2004

\section{Financial Distress}

Financial distress merupakan kondisi dimana perusahaan mengalami ketidakmampuan dalam membayar kewajibannya jangka pendeknya ketika jatuh tempo karena perusahaan kekurangan dana. Menurut Altman dan Hotchkiss financial distress merupakan suatu kondisi dimana perusahaan menghadapi berbagai permasalahan ekonomi yang sulit, diantaranya kegagalan (failure), kepailitan (insolvency), gagal bayar (default) hingga kebankrutan (bankruptcy). Financial distress juga dapat diartikan perbankan dalam tahap yang dekat dengan kebangkrutan yang ditandai dengan ketidakpastian profitabilitas perusahaan masa yang akan datang. Terdapat beberapa metode yang bisa digunankan untuk memprediksi terjadinya kebangkrutan yaitu metode Z-score Atlman, Springrate, Zmijewski, dan Grover (Halimatusadiah \& Gunwan, 2014).

\section{Metode Zmijewski}

Metode zmijewski merupakan metode probit yang merupakan salah satu alternatif analasis regresi yang menggunakan distribusi probabilitas normal komulatif melalui rasio keuangan yang dapat 
mengukur kinerja perusahaan, Levarage, dan likuiditas untuk memprediksi financial distress (Rahmat, 2020). Metode ini bisa digunakan untuk lanjutan dari metode RGEC untuk menganalisis kesehatan bank lalu kemudian dianalisis lebih lanjut dengan menggunakan analisis Zmijewski untuk memprediksi potensi kebangkrutan. Tingkat keakuratan analisis Zmijewski untuk memprediksi potensi kebangkrutan adalah sebesar 94,9\% (Halimatusyakdiah et al., 2015). Kriteria penilaian metode Zmijewski jika Z $<0,5$ maka perusahaan dapat dikatakan sehat, adapun persamaan model dari Zmijewski adalah:

$$
Z=-4,3-4,5 X 1+5,7 \times 2-0,004 \times 3
$$

Dimana;

$\mathrm{X} 1$ = Laba setelah pajak/Total Aktiva

$\mathrm{X} 2$ = Total utang/Total Aktiva

X3 = Aktiva lancar/Kewajiban lancar

\section{METODE PENELITIAN}

Jenis metode yang digunakan dalam penelitian ini adalah penelitian analisis deskriptif. Analisis deskriptif adalah metode yang digunakan untuk menyajikan data kuantitatif yang kemudian dideskriptifkan. Analisis deskriptif menggambarkan data dengan apa adanya. Data biasanya disajikan dalam bentuk table atau grafik maupun angka.

Jenis data yang digunakan dalam penelitian ini adalah data sekunder. Objek penelitian ini adalah laporan keuangan BNI Syariah periode 2015-2019. Teknik pengumpulan data yang digunakan dalam penelitian ini adalah teknik dokumentasi. Teknik dokumentasi merupakan salah satu metode dalam pengumpulan data melalui dokumen berupa buku, jurnal, laporan perusahaan, surat, dan lainlain. Sehingga data yang digunakan dalam penelitian ini adalah laporan keuangan PT BNI Syariah periode 2015-2019, dan data studi kepustakaan berupa buku dan jurnal yang sesuai dengan penelitian.

Teknik analisis data yang digunakan dalam penelitian ini adalah analisis tingkat kesehatan bank menggunakan metode RGEC yang meliputi komponen Risk Profile menggunakan indikator NPF dan FDR, Good Corporate Governance menggunakan indikator PDN, Earnings menggunakan indikator ROA, ROE, NI dan BOPO, Capital menggunakan indikator CAR yang kemudian akan diklasifikasikan berdasarkan Peraturan Bank Indonesia Nomor 6/10/PBI/2004 mengenai tingkat kesehatan bank dan juga dilakukan analisis potensi financial distress menggunakan metode Zmijewski

\section{HASIL DAN PEMBAHASAN}

\section{Hasil Analisis Tingkat Kesehatan BNI Syariah 2015-2019 Menggunakan Metode RGEC}

Analisis tingkat kesehatan bank BNI Syariah periode 2015-2019 dapat diukur menggunakan hasil analisa dari laporan keuangan dengan metode RGEC melalui Risk Profile, Good Corporate Governance, Earnings dan Capital.

1. Risk Profile diukur melalui risiko kredit menggunakan indikator NPF dan risiko likuiditas menggunakan FDR.

a. Risiko kredit menggunakan Non Performing Finance.

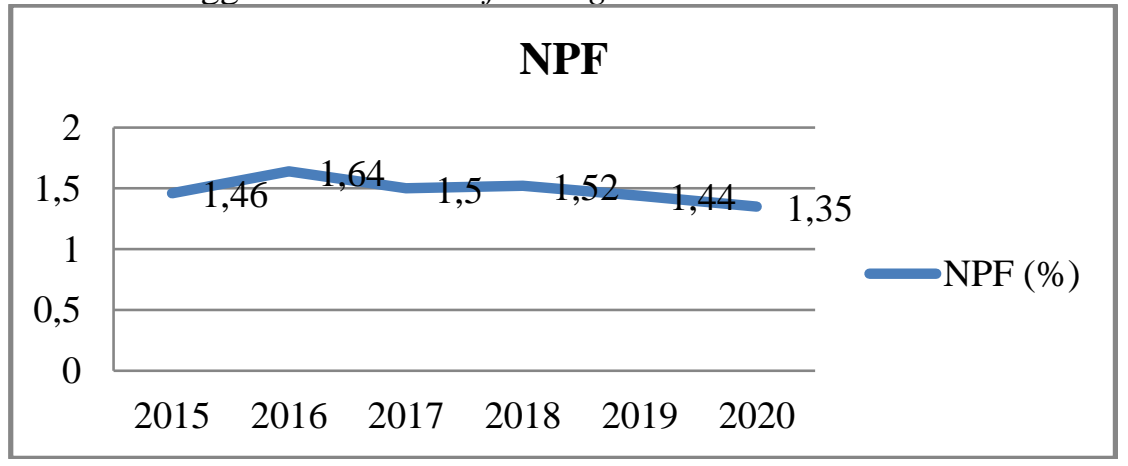

Sumber: Data diolah

Gambar 1.

Grafik Hasil Peniliaian Rasio NPF BNI Syariah Tahun 2015-2019 
Error! Reference source not found. menunjukkan bahwa NPF pada laporan keuangan BNI Syariah pada tahun 2015 sebesar 1,46\%. Kemudian pada tahun 2016 NPF BNI Syariah mengalami kenaikan sebesar 0,18\% menjadi 1,64\%. Namun pada tahun 2017 BNI Syariah berhasil menurunkan angka NPF seebsar 0.14\% menjadi 1,5 dan pada tahun 2018 NPF BNI Syariah mengalami sedikit kenaikan sebanyak 0,02\% sehingga NPF 2018 menjadi sebesar 1,52\%. Pada tahun 2019 NPF BNI Syariah mengalami penurunan yang cukup signifikan sebanyak 0,08\% sehingga NPF 2019 menjadi sebesar $1,44 \%$. Terakhir pada tahun 2020, NPF BNI Syariah mengalami penurunan kembali manjadi sebesar $1.35 \%$

b. Risiko likuiditas menggunakan FDR.

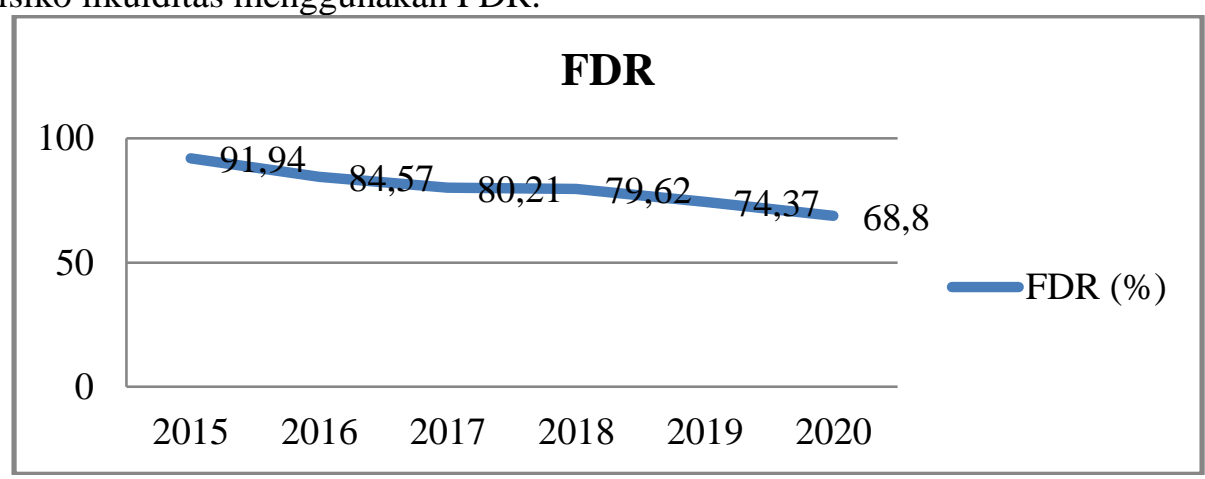

Sumber: Data diolah

Gambar 2.

Grafik Hasil Penilaian Rasio FDR BNI Syariah tahun 2015-2019

Error! Reference source not found. menunjukkan bahwa FDR pada laporan keuangan BNI Syariah pada tahun 2015 sebesar 91,94\%. Kemudian pada tahun 2016, FDR di bank BNI Syariah mengalami penurunan sebesar 7,37\% sehingga FDR di Bank BNI Syariah pada tahun 2016 menjadi sebesar 84,57\%. Pada tahun 2017, FDR Bank BNI syariah kembali mengalami penurunan sebesar $4.36 \%$ sehingga menjadi sebesar $80.21 \%$. Pada tahun 2018 FDR Bank BNI syariah mengalami sedikit penurunan sebesar $0.59 \%$ sehingga FDR pada tahun 2018 adalah sebesar 79,62\%. Pada tahun 2019, FDR bank BNI Syariah mengalami penurunan kembali sebesar 5.25\% sehingga FDR Bank BNI Syariah pada tahun 2019 adalah sebesar 74.37\%. Terakhir pada tahun 2020, Posisi FDR Bank BNI Syariah kembali mengalami penurunan menjadi sebesar $68.8 \%$

2. GCG diukur Melalui PDN

a. Posisi Devisa Neto (PDN)

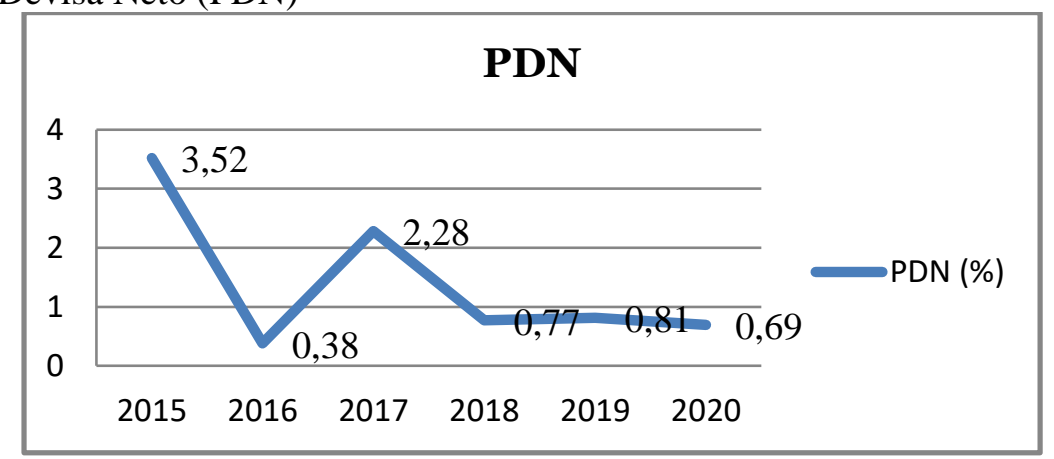

Sumber: Data diolah

Gambar 3.

Grafik Hasil Penilaian Rasio PDN BNI Syariah Tahun 2015-2019

Berdasarkan informasi dari Gambar 3 tentang Grafik Hasil Penilaian Rasio PDN BNI Syariah Tahun 2015-2019 dapat diketahui bahwa posisi PDN Bank BNI Syariah pada tahun 2015 adalah sebesar $3.52 \%$. Kemudian pada tahun 2016 mengalami penurunan yang cukup signifikan yaitu penurunannya sebesar 3.14\% sehingga pada tahun 2016 posisi PDN Bank BNI Syariah menjadi 0.38\%. Pada tahun 2017, posisi PDN mengalami kenaikan sebesar 1.9\% sehingga pada tahun 2017 PDN berada pada angka 2.28\%. Pada tahun 2018, PDN Bank BNI Syariah kembali mengalami penurunan yang signifikan seperti pada tahun 2016 yaitu penurunannya sebesar $1.51 \%$ sehingga posisi PDN pada tahun 2018 berubah menjadi $0.77 \%$. Kemudian pada tahun 2019 posisi PDN hanya sedikit mengalami kenaikan 
menjadi sebesar 0.81\%. Terakhir pada tahun 2020, Posisi PDN Bank BNI Syariah kembali mengalami penurunan menjadi sebesar $0.69 \%$

3. Earnings diukur melalui ROA, ROE, NI, dan BOPO

a. Return On Assets (ROA)

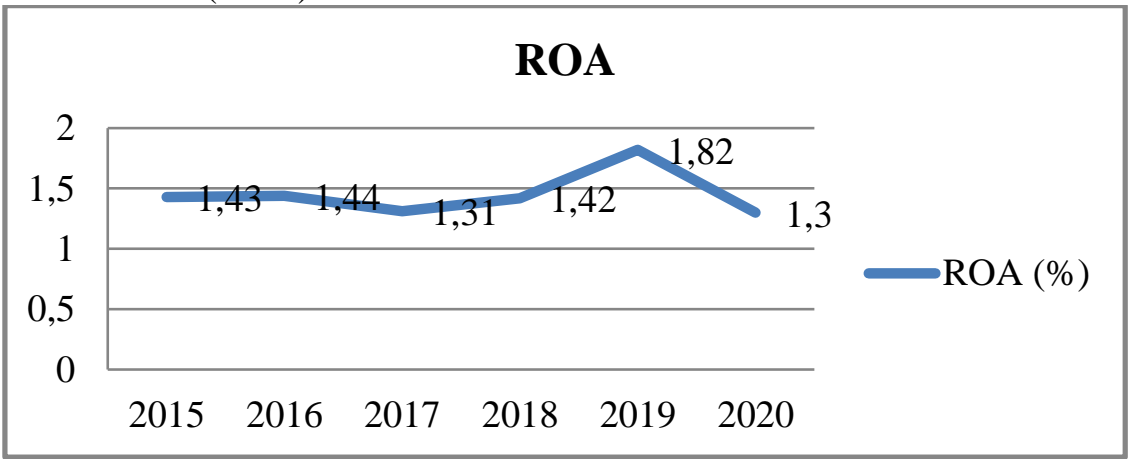

Sumber: Data diolah

Gambar 4.

Grafik Hasil Penilaian Rasio ROA BNI Syariah Tahun 2015-2019

Berdasarkan informasi dari Gambar 4, Grafik Hasil Penilaian Rasio ROA BNI Syariah Tahun 2015-2019 dapat diketahui bahwa posisi ROA Bank BNI Syariah pada tahun 2015 adalah sebesar 1.43\%. Kemudian pada tahun 2016 mengalami sedikit kenaikan sebesar $0.01 \%$ sehingga pada tahun 2016 posisi ROA Bank BNI Syariah menjadi 1.44\%. Pada tahun 2017, posisi ROA mengalami penurunan sebesar $0.13 \%$ sehingga pada tahun 2017 ROA berada pada angka 1.31\%. Pada tahun 2018, ROA Bank BNI Syariah kembali mengalami sedikit kenaikan seperti pada tahun 2016 yaitu penurunannya sebesar $0.12 \%$ sehingga posisi ROA pada tahun 2018 berubah menjadi $1.42 \%$. Kemudian pada tahun 2019 posisi ROA mengalami kenaikan menjadi sebesar $1.82 \%$. Terakhir pada tahun 2020, Posisi ROA Bank BNI Syariah kembali mengalami penurunan menjadi sebesar 1.3\%.

b. Return On Equity (ROE)

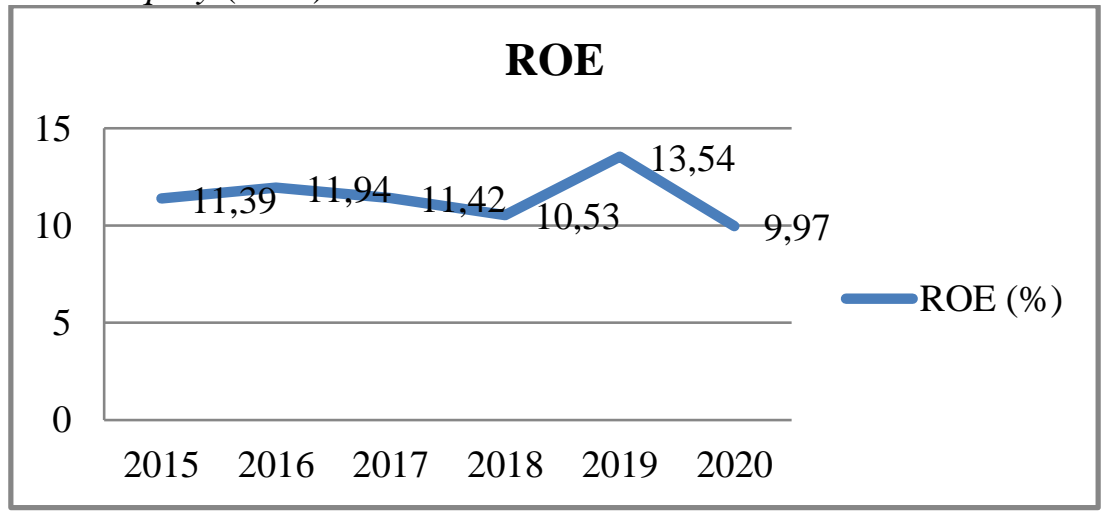

Sumber: Data diolah

Gambar 5.

Hasil Penilaian Rasio ROE BNI Syariah Tahun 2015-2019

Berdasarkan informasi dari Gambar 5. Grafik Hasil Penilaian Rasio ROE BNI Syariah Tahun 2015-2019 dapat diketahui bahwa posisi ROE Bank BNI Syariah pada tahun 2015 adalah sebesar $11.39 \%$. Kemudian pada tahun 2016 mengalami sedikit kenaikan sebesar $0.55 \%$ sehingga pada tahun 2016 posisi ROE Bank BNI Syariah menjadi 11.94\%. Pada tahun 2017, posisi ROE mengalami penurunan sebesar $0.52 \%$ sehingga pada tahun 2017 ROE berada pada angka $11.42 \%$. Pada tahun 2018, ROE Bank BNI Syariah kembali mengalami penurunan lagi sebesar $10.53 \%$ sehingga posisi ROE pada tahun 2018 berubah menjadi 10.53\%. Kemudian pada tahun 2019 posisi ROE mengalami kenaikan menjadi sebesar 13.54\%. Terakhir pada tahun 2020, Posisi ROE Bank BNI Syariah kembali mengalami penurunan menjadi sebesar $9.97 \%$

c. Net Imbalan (NI) 


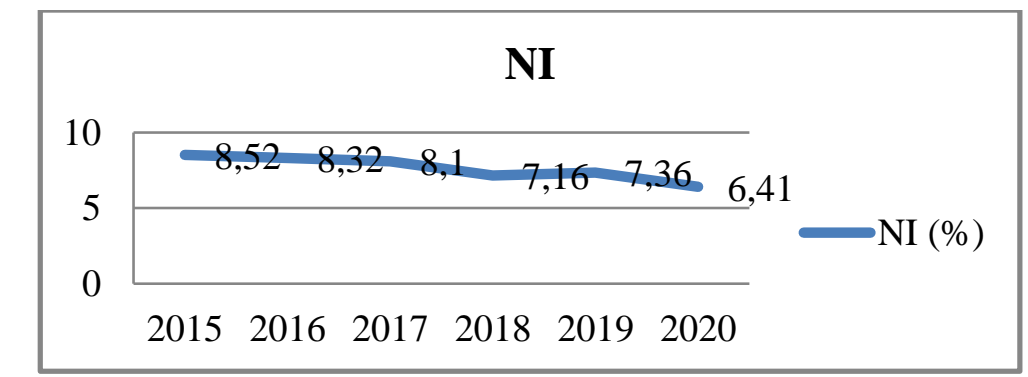

Sumber: Data diolah

\section{Gambar 6.}

Hasil Penialaian Rasio NI BNI Syariah Tahun 2015-2019

Berdasarkan informasi dari Gambar 6. Grafik Hasil Penilaian Rasio NI BNI Syariah Tahun 2015-2019 dapat diketahui bahwa posisi NI Bank BNI Syariah pada tahun 2015 adalah sebesar 8.52\%. Kemudian pada tahun 2016 mengalami sedikit penurunan sebesar $0.20 \%$ sehingga pada tahun 2016 posisi NI Bank BNI Syariah menjadi 8.32\%. Pada tahun 2017, posisi NI mengalami penurunan lagi sebesar $0.22 \%$ sehingga pada tahun 2017 NI berada pada angka 8.10\%. Pada tahun 2018, NI Bank BNI Syariah kembali mengalami penurunan lagi sebesar $0.94 \%$ sehingga posisi NI pada tahun 2018 berubah menjadi 7.16\%. Kemudian pada tahun 2019 posisi NI mengalami kenaikan menjadi sebesar $7.36 \%$. Terakhir pada tahun 2020, Posisi NI Bank BNI Syariah kembali mengalami penurunan menjadi sebesar $6.41 \%$

d. Biaya Operasional terhadap Pendapatan Operasional (BOPO).

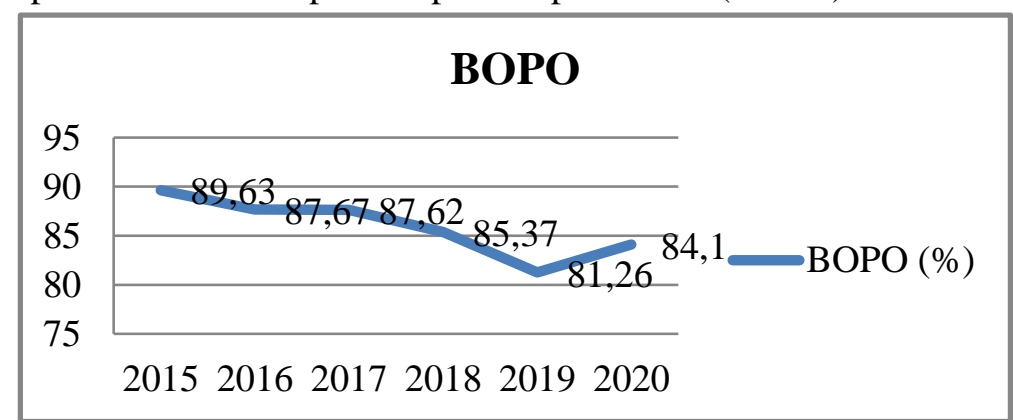

Sumber: Data diolah

Gambar 7.

Grafik Hasil Penilaian Rasio BOPO BNI Syariah Tahun 2015-2019

Berdasarkan informasi dari Gambar 6. Grafik Hasil Penilaian Rasio BOPO BNI Syariah Tahun 2015-2019 dapat diketahui bahwa posisi BOPO Bank BNI Syariah pada tahun 2015 adalah sebesar 89.63\%. Kemudian pada tahun 2016 mengalami penurunan sebesar $1.96 \%$ sehingga pada tahun 2016 posisi BOPO Bank BNI Syariah menjadi 87.67\%. Pada tahun 2017, posisi BOPO mengalami sedikit penurunan lagi sebesar $0.05 \%$ sehingga pada tahun 2017 BOPO berada pada angka $87.62 \%$. Pada tahun 2018, BOPO Bank BNI Syariah kembali mengalami penurunan cukup signifikan sebesar $2.25 \%$ sehingga posisi BOPO pada tahun 2018 berubah menjadi 85.37\%. Kemudian pada tahun 2019 posisi BOPO mengalami penurunan menjadi sebesar $81.26 \%$. Terakhir pada tahun 2020, Posisi BOPO Bank BNI Syariah kembali mengalami peningkatan menjadi sebesar $84.1 \%$

4. Capital diukur melalui CAR

a. Capital Adequacy Ratio (CAR)

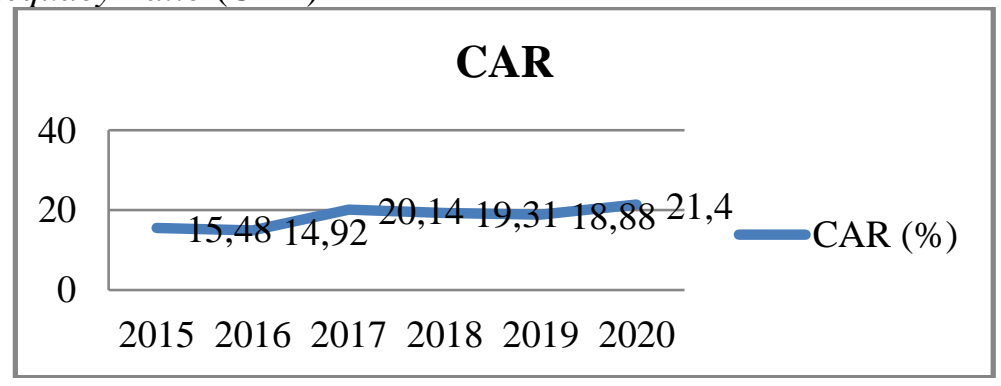

Sumber: Data diolah 
Gambar 8.

Grafik Hasil Penilaian Rasio CAR BNI Syariah Tahun 2015-2019

Berdasarkan informasi dari Gambar 8 Grafik Hasil Penilaian Rasio CAR BNI Syariah Tahun 2015-2019 dapat diketahui bahwa posisi CAR Bank BNI Syariah pada tahun 2015 adalah sebesar 15.48\%. Kemudian pada tahun 2016 mengalami penurunan sebesar $0.56 \%$ sehingga pada tahun 2016 posisi CAR Bank BNI Syariah menjadi 14.92\%. Pada tahun 2017, posisi CAR mengalami peningkatan yang cukup tajam sebesar 5.22\% sehingga pada tahun 2017 CAR berada pada angka $20.14 \%$. Pada tahun 2018, CAR Bank BNI Syariah kembali mengalami sedikit penurunan sebesar 0.83\% sehingga posisi CAR pada tahun 2018 berubah menjadi 19.31\%. Kemudian pada tahun 2019 posisi BOPO mengalami penurunan menjadi sebesar $18.88 \%$. Terakhir pada tahun 2020, Posisi CAR Bank BNI Syariah kembali mengalami peningkatan menjadi sebesar $21.4 \%$

\section{Analisis Tingkat Kesehatan BNI Syariah 2015-2019 Menggunakan Metode RGEC}

Analisis tingkat kesehatan bank dapat diukur menggunakan hasil analisa dari laporan keuangan dengan metode RGEC melalui Risk Profile, Good Corporate Governance, Earnings dan Capital. Analisa Risk Profile dapat diukur melalui risiko kredit menggunakan indikator NPF dan risiko likuiditas menggunakan FDR. Jumlah NPF di Bank BNI Syariah pada tahun 2015 adalah sebesar 1,46\%, angka tersebut termasuk dalam kategori sangat sehat. Kemudian pada tahun 2016 jumlah NPF mengalami sedikit peningkatan yaitu menjadi 1,64\% namun tidak merubah kategori sebelumnya yaitu masih dalam kategori sangat sehat. Pada tahun 2017 NPF di Bank BNI Syariah mengalami penurunan menjadi sebesar 1,5\% dan kategori pada tahun 2017 tetap pada kategori sangat sehat. Kemudian pada tahun 2018 kembali mengalami kenaikan menjadi sebesar 1,52 dan untuk kategorinya masih sama yaitu sangat sehat. Pada tahun 2019 NPF di Bank BNI Syariah kembali mengalami penurunan yang cukup signifikan yaitu menjadi sebesar 1,44\%. Terakhir pada tahun 2020, NPF bank BNI Syariah mengalami penurunan kembali menjadi sebesar 1,35\% dan berada pada kategori sehat. NPF pada tahun 2020 adalah NPF yang paling rendah yang pernah dialami oleh Bank BNI Syariah selama 5 tahun terakhir dan tetap pada kategori sangat sehat. Secara keseluruhan, hasil analisa NPF pada laporan keuangan BNI Syariah periode 2015 hingga 2020 masuk dalam kategori "Sangat Sehat" hal ini menunjukkan bahwa BNI syariah mampu mengelola pembiayaan yang disalurkan dengan sangat baik sehingga risiko kredit dapat diatasi.

Indikator yang kedua untuk Risk Profile adalah FDR. FDR di Bank BNI Syariah pada tahun 2015 adalah sebesar 91.94\%. Angka tersebut termasuk dalam kategori cukup sehat. Pada tahun 2016 FDR di Bank BNI Syariah mengalami perbaikan yaitu menjadi $84.57 \%$ sehingga merubah kategori dari yang sebelumnya cukup sehat menjadi kategori sehat. Pada tahun 2017, FDR di Bank BNI Syariah kembali mengalami penurunan menjadi sebesar $80.21 \%$ namun kategorinya masih tetap yaitu sehat. Pada tahun 2018, FDR Bank BNI Syariah mengalami sedikit penurunan menjadi 79.62\% namun untuk kategori masih sama dengan tahun 2016 dan 2017 yaitu kategori sehat. Terakhir pada tahun 2019, FDR Bank BNI Syariah mengalami penurunan kembali yaitu sebesar $74.37 \%$ dan mampu merubah kategori menjadi kategori sangat sehat. Terakhir pada tahun 2020, Posisi FDR Bank BNI Syariah kembali mengalami penurunan menjadi sebesar $68.8 \%$ dan mempertahankan predikat kategori sangat sehat. Secara keseluruhan, hasil analisa perhitungan FDR pada laporan keuangan BNI Syariah periode 2015 hingga 2020 mendapatkan predikat "Sehat". hal ini menunjukkan bahwa BNI syariah mampu mengelola pembiayaan yang disalurkan dengan baik sehingga risiko likuiditas dapat diatasi dengan baik.

Setelah Risk Profile, Analisa yang kedua adalah tentang Analisa Good Corporate Governance yang dapat diukur melalui Posisi Devisa Netto (PDN). Berdasarkan hasil penelitian posisi PDN Bank BNI Syariah pada tahun 2015 sampai dengan tahun 2020 tidak pernah berada diatas 10\% namun juga tidak pernah berada diposisi 0\% sehingga dapat disimpulkan bahwa Bank BNI Syariah berada dalam kategori cukup sehat selama 5 tahun. Penurunan PDN BNI Syariah dari 3,52\% pada tahun 2015 hingga 0,69\% pada tahun 2020 menunjukkan bahwa tingkat efisiensi pengelolaan manajemen perbankan terkait dengan Posisi Devisa Neto (PDN) tergolong cukup baik.

Analisa yang ketiga adalah Analisa Earnings. Ada 4 indikator untuk menganalisa earnings pada perbankan yaitu adalah ROA, ROE, dan NI dan BOPO. Indikator yang pertama adalah ROA. Berdasarkan hasil Analisa, secara keseluruhan ROA pada laporan keuangan BNI Syariah pada tahun 
2015 hingga 2020 mendapatkan predikat "Sehat". Penurunan ROA BNI Syariah dari 1,43\% pada tahun 2015 hingga 1,3\% pada tahun 2020 menunjukkan bahwa tingkat efisiensi pengelolaan aset BNI Syariah untuk memperoleh laba tergolong baik. Kemudian untuk indikator yang kedua yaitu ROE. Berdasarkan hasil analisa, secara keseluruhan ROE pada laporan keuangan BNI Syariah pada tahun 2015 hingga 2020 mendapatkan predikat yang sama dengan ROA yaitu "Sehat". Peningkatan ROE BNI Syariah dari 11,39\% pada tahun 2015 hingga 13.54\% pada tahun 2019 menunjukkan bahwa tingkat efisiensi pengelolaan modal BNI Syariah untuk menghasilkan laba tergolong baik, semakin tinggi ROE maka nilai perusahaan di mata investor akan semakin baik. Selanjutnya adalah indikator yang ketiga yaitu NI. Berdasarkan hasil analisa, secara keseluruhan NI pada laporan keuangan BNI Syariah pada tahun 2015 hingga 2020 mendapatkan predikat "Sangat Sehat". Penurunan NI BNI Syariah dari 8,52\% pada tahun 2015 hingga 6,41\% pada tahun 2020 menunjukkan bahwa terdapat penurunan tingkat efisiensi dan efektivitas pengelolaan aset produktif BNI Syariah untuk menghasilkan laba meskipun masih tergolong sangat baik. Akan tetapi, perbankan perlu membenahi manajemen aset produktif agar tidak terjadi penurunan di masa yang akan datang. Indikator yang terakhir adalah mengenai BOPO. Berdasarkan hasil analisa, Secara keseluruhan BOPO pada laporan keuangan BNI Syariah pada tahun 2015 hingga 2019 mendapatkan predikat "Sangat Sehat". Penurunan BOPO BNI Syariah dari 89,63\% pada tahun 2015 hingga $84.1 \%$ pada tahun 2020 menunjukkan bahwa terdapat peningkatan tingkat efisiensi dan efektivitas dalam pengelolaan operasional BNI Syariah untuk memperoleh pendapatan sehingga tergolong sangat baikError! Reference source not found.

Analisa yang terakhir adalah Analisa tentang Capital. Analisa Capital dapat dilihat melalui indicator CAR. Berdasarkan hasil penelitian, Secara keseluruhan CAR pada laporan keuangan BNI Syariah pada tahun 2015 hingga 2020 mendapatkan predikat "Sangat Sehat". Peningkatan CAR BNI Syariah dari 15,48\% pada tahun 2015 hingga 21.4\% pada tahun 2019 menunjukkan bahwa kecukupan modal BNI Syariah sangat baik sehingga mampu menanggung setiap risiko dari pembiayaan atau aktiva produktif yang beresiko dan memiliki potensi yang lebih besar untuk memperoleh keuntungan. Secara umum tingkat kesehatan BNI Syariah tahun 2015-2019 menggunakan metode RGEC yang diukur melalui delapan komponen (NPF, FDR, PDN, ROA, ROE, NI, BOPO dan CAR) mendapatkan predikat "Sangat Sehat".

\section{Analisis Potensi Financial Distress BNI Syariah periode 2015-2019 Menggunakan Metode Zmijewski}

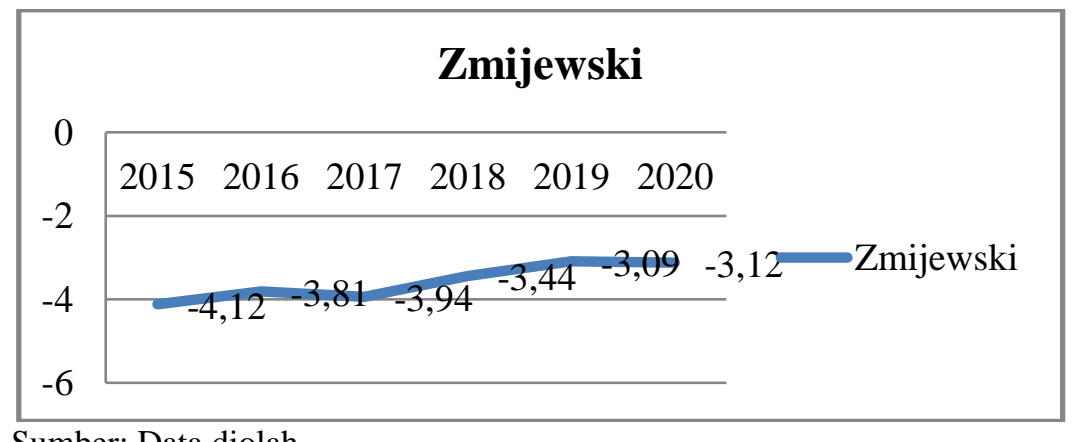

Sumber: Data diolah

Gambar 9.

Grafik Hasil Analisis Potensi Financial Distress Metode Zmijewski BNI Syariah Tahun 2015-2020

Berdasarkan hasil analisis perhitungan statistik menggunakan metode Zmijewski pada laporan keuangan BNI Syariah tahun 2015-2020 sebesar -4,12 pada tahun 2015, -3,81 pada tahun 2016, -3,94 pada tahun 2017, $-3,44$ pada tahun 2018, dan $-3,09$ pada tahun 2019 dan -3.12 pada tahun 2020 dimana hasil tersebut $<0,5$ menunjukkan bahwa pada tahun 2015 hingga 2020 BNI Syariah dikategorikan dalam keadaan stabil dan tidak berpotensi mengalami kebangkrutan. Hal ini sejalan dengan hasil analisis tingkat kesehatan metode RGEC yang mendapatkan predikat "Sangat Sehat".

\section{SIMPULAN}

Tingkat Kesehatan Bank dapat diukur dengan menggunakan metode RGEC. Dalam penilaian kesehatan bank menggunakan metode RGEC terdapat empat komponen utama yang diukur yaitu Risk Profile, Good Corporate Governance, Earnings dan Capital. Analisa RGEC yang pertama adalah 
tentang Analisa Risk Profile yang dapat diukur melalui NPF dan FDR. Berdasarkan hasil penelitian, NPF Bank BNI Syariah selama 5 tahun terakhir mendapatkan predikat sangat sehat dan FDR Bank BNI Syariah mendapatkan predikat sehat. Kemudian analisa yang kedua adalah tentang Good Corporate Governance yang dapat diukur melalui PDN. Berdasarkan analisa, PDN Bank BNI Syariah termasuk dalam kategori cukup sehat selama 5 tahun terakhir. Kemudian Analisa yang ketiga adalah tentang earnings yang dapat dilihat dari ROA, ROE, NI, dan BOPO. Berdasarkan Analisa 5 tahun terakhir, ROA dan ROE masuk dalam kategori sehat sedangkan NI dan BOPO masuk dalam kategori sangat sehat. Analisa yang terakhir adalah tentang Capital yang dapat dilihat dari CAR. Berdasarkan Analisa 5 tahun terakhir, CAR pada Bank BNI Syariah mendapatkan kategori sangat sehat. Secara umum tingkat kesehatan BNI Syariah tahun 2015-2020 menggunakan metode RGEC yang diukur melalui delapan komponen (NPF, FDR, PDN, ROA, ROE, NI, BOPO dan CAR) mendapatkan predikat "Sangat Sehat". Selain itu, hasil penelitian dari analisis potensi financial distress BNI Syariah periode 2015 hingga 2020 menggunakan metode Zmijewski juga menunjukkan bahwa BNI Syariah dalam keadaan stabil dan tidak berpotensi mengalami financial distress. Hal tersebut menunjukkan bahwa kinerja BNI Syariah periode 2015 hingga 2020 termasuk dalam kategori sangat baik dan mampu menghadapi pengaruh negatif dari fluktuasi bisnis yang dihadapi.

\section{DAFTAR PUSTAKA}

Adhim, C. (2019). Pengaruh resiko kredit, resiko likuiditas, efisiensi manajemen terhadap profitabilitas: Studi pada perbankan yang terdaftar di bursa efek Indonesia. Cendekia: Jurnal Pendidikan dan Pembelajaran, 13(2), 141-152. https://doi.org/10.30957/cendekia.v13i2.604

Anik., \& Ningsih, S. (2020). Analisis tingkat kesehatan bank mandiri syariah dengan metode risk profile, good corporate governace, earnings, and capital. Jurnal Ilmiah Ekonomi Islam, 6(13), 724-730.

Ardyanfitri, H., Pratikto, M. I. S., \& Faizah, E. A. K. (2019). Analisis kesehatan bank dan potensi financial distress menggunakan metode RGEC pada bank BTPN Syariah tahun 2014-2018. Jurnal MEBIS (Manajemen dan Bisnis), 4(2), 131-141. https://doi.org/10.33005/mebis.v4i2.63

Dewi, E. T., \& Srihandoko, W. (2018). Pengaruh risiko kredit dan risiko likuiditas terhadap profitabilitas bank. Jurnal Ilmiah Manajemen Kesatuan, 6(3), 131-138. https://doi.org/10.37641/jimkes.v6i3.294

Halimatusadiah, E., \& Gunwan, B. (2014). Analisis penerapan good corporate governance dalam mengoptimalkan pelaksanaan sistem informasi akuntansi. Jurnal Riset Akuntansi dan Keuangan, 2(1), 300. https://doi.org/10.17509/jrak.v2i1.6583

Halimatusyakdiah, Kosim, A., \& Meirawati, E. (2015). Analisis financial distress pada industri kosmetik yang terdaftar di bursa efek Indonesia (BEI) untuk memprediksi potensi kebangkrutan perusahaan. Akuntabilitas: Jurnal Penelitian dan Pengembangan Akuntansi, 9(2), 125-140.

Pratikto, M. I. S., Qanita, A., \& Maghfiroh, R. U. (2019). Analisis tingkat kesehatan dan potensi financial distress dengan metode RGEC pada BNI Syariah tahun 2014-2018. EL-Qist, 9(1), 87101.

Rahmat. (2020). Analisis financial distress menggunakan model Altman Z-Score. Jurnal ASET (Akuntansi Riset), 12(1), 1-16. https://doi.org/10.17509/jaset.v12i1.23062

Samanto, H., \& Hidayah, N. (2020). Penilaian tingkat kesehatan bank dengan menggunakan metode REC pada PT Bank BRI Syariah Tbk periode 2014-2018, 6(3), 709-715.

Sirait, H., Citarayani, I., \& Quintania, M. (2020). Pengaruh tingkat kesehatan bank dengan metode RGEC (Risk profile, good corporate governance, earnings, capital) dan strategi diversifikasi terhadap pertumbuhan laba. Journal of Management Review, 4(1).

Suryanto, A., \& Refianto. (2019). Analisis pengaruh penerapan good corporate governance terhadap kinerja keuangan. Jurnal Bina Manajemen, 8(1), 1-33.

Tho'in, M., \& Irawati, T. (2018). Risk and financial health level of sharia banking. Journal Research and Analysis: Economy, 1(1), 19-26.

Wahasusmiah, R., \& Watie, K. R. (2018). Metode RGEC: Penilaian tingkat kesehatan. I-Finance, 04(02), 170-184. 